\title{
MAHAR DAN UANG PANAIK PERKAWINAN PADA TRADISI MASYARAKAT DALAIM PANDANGAN HUKUM ISLAM (Studi Kasus di Kelurahan Limpomajang Kacamatan Marioriawa Kabupaten Soppeng)
}

\author{
Muhammad Iqbal ${ }^{1}$, Sudirman $\mathbf{L}^{2}$ \\ UIN Alauddin Makassar ${ }^{1}$ \\ Institut Agama Islam Negeri Pare-Pare ${ }^{2}$
}

\begin{abstract}
This study aims to analyze the legal status in Islam regarding dowry and panaik money in Limpomajang Village, Marioriawa District, Soppeng Regency. In the process of collecting data, the writer used the method of observation and interviews with the village head, religious leaders, community leaders and youth leaders. In various sources found by the author, both the Quran, hadiths and the opinions of scholars, dowry is a gift that must be fulfilled and submitted by the prospective groom to the prospective bride, namely in the form of goods or services that have value and benefit, usually in the form of rings gold, rice fields, gardens and a set of prayer tools. Meanwhile, panaik money is the giving of a certain amount of money from the prospective groom to the prospective bride as a walimah fee. Dowry and Panaik money still exist and are used as conditions for marriage in Limpomajang Village, Marioriawa District, Soppeng Regency. Islamic law views that a dowry is a legal condition of marriage as the author finds in the Alquran and the Hadith of the Prophet. Meanwhile, panaik money is not found in various references to both the Quran and the Hadith of the Prophet, but only historical evidence so that it becomes a tradition and custom in society. It is known that religion forbids making it difficult for a marriage to take place, but panaik money is a heavy burden for men. Seeing the large amount of panaik money, it can bring harm or something bad for a marriage. So the authors conclude that panaik money is makruh and even haram when the method of obtaining panaik money is not in accordance with Islamic law.
\end{abstract}

Keywords:

\section{PENDAHULUAN}

Perkawinan merupakan suatu perkara yang disyariatkan dalam ajaran islam dan merupakan sunnah dari Rasulullah SAW, agar setiap umatnya mendapatkan keturunan dan keluarga yang sah dalam lingkungan masyarakat serta mampu mendapatkan kebahagiaan di dunia dan di akhirat. Selain daripada itu, perkawinan juga telah dianjurkan oleh Allah SWT sebagaimana didalam Firman-Nya Q.S Ar Rum (30) : 21 :
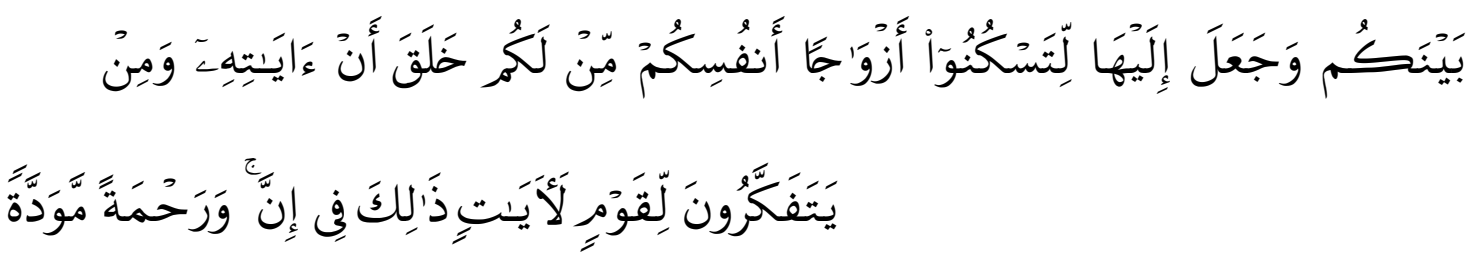
Terjemahnya:

Dan diantara tanda-tanda kekuasaan-Nya ialah Dia menciptakan untukmu istriistri dari jenismu sendiri, supaya kamu cenderung dan merasa tenteram kepadanya, dan dijadikan-Nya diantaramu rasa kasih dan sayang. Sesungguhnya pada yang demikian itu benar-benar terdapat tanda-tanda bagi kaum yang berfikir. ${ }^{1}$

Ayat diatas dapat dipahami bahwa sesungguhnya perkawinan merupakan sebuah ketetapan yang diperintahkan Allah kepada hamba-Nya dalam hal ini adalah manusia. Pada hakikatnya bahwa menikah akan membuat setiap manusia dapat tentram atau dengan kata lain akan mendapatkan kebahagiaan dunia dan akhirat. Namun dalam Perkawinan tersebut, tentu ada syarat yang perlu dipenuhi dalam melangsungkan Perkawinan. Sebagai salah satunya adalah calon mempelai perempuan memiliki hak untuk menerima mahar/maskawin sehingga calon mempelai laki-laki wajib memberikan mahar atau maskawin kepada calon mempelai perempuan. Sebagaimana perintah Allah SWT di dalam Firman-Nya Q.S An Nisa (4) : 4 :

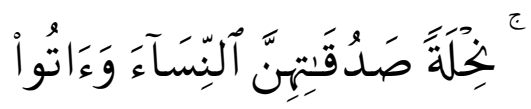

Terjemahnya :

Berikanlah maskawin (mahar) kepada wanita (yang kamu nikahi) sebagaimana pemberian dengan penuh kerelaan.... ${ }^{2}$

Allah memerintahkan atau mewajibkan seorang calon suami untuk memberikan sebuah mahar atau maskawin kepada calon istrinya sebagai bentuk kerelaanya. Selain diperintahkan oleh Allah juga akan bermanfaat kepada calon istrinya karena mahar tersebut akan dikuasai penuh oleh seorang istri dan hanya bisa diberikan kepada suami jika istri rela untuk memberikannya.

Perkawinan dalam tradisi suku Bugis-Makassar khususnya di Kelurahan Limpomajang Kecamatan Marioriawa Kabupaten Soppeng telah diketahui bahwa ada tradisi Uang Panaik yaitu sejumlah uang yang harus disiapkan oleh calon suami untuk diserahkan kepada calon istrinya. Namun antara Uang Panaik dengan Mahar adalah dua hal yang berbeda, karena Uang Panaik dalam tradisi bugis-makassar merupakan sejumlah uang yang harus diberikan calon istri dari calon suaminya untuk digunakan atas biaya-biaya dalam penyelenggaraan perkawinan. Sehingga Uang Panaik tersebut, akan habis digunakan dan tidak akan ada yang dimiliki atau disimpan oleh calon istri. Uang Panaik tidak ditemukan dasar hukumnya baik di dalam Alquran maupun di dalam Hadis Nabi. Namun ini merupakan aturan penting dalam Tradisi Masyarakat Sulawesi Selatan khususnya Kelurahan Limpomajang Kecamatan Marioriawa Kabupaten Soppeng, sehingga dapat diketahui bahwa sangatlah berbeda antara mahar dengan Uang Panaik.

\footnotetext{
${ }^{1}$ Departemen Agama RI., Al-Qur'an dan Terjemahnya (Semarang: Toha Putra,1989), h. 644

${ }^{2}$ Ibid., h. 115.
} 
Uang Panaik menjadi fenomena besar dikalangan masyarakat Limpomajang, karena seorang calon suami akan terbebani dengan adanya persyaratan yang wajib dipenuhi berupa uang dengan jumlah yang besar dan juga persyaratan dalam islam berupa mahar/maskwin seperti cincin, kalung, gelang, sepetak sawah, alat shalat dan lain lain.

Berdasarkan dari uraian dalam pengantar diatas, maka yang akan menjadi fokus masalah dalam tulisan ini adalah sebagai berikut :

1. Bagaimana eksistensi Mahar dan Uang Panaik dalam pelaksanaan Perkawinan dalam tradisi masyarakat di Kelurahan Limpomajang Kecamatan Marioriawa Kabupaten Soppeng ?

2. Bagaimana pandangan hukum islam mengenai penerapan kewajiban mahar dan Uang Panaik yang harus dipenuhi oleh seorang calon suami kepada calon istrinya?

\section{KAJIAN TEORI}

\section{A. Perkawinan}

Dalam Kamus bahasa Indonesia kata "Perkawinan" berasal dari kata "kawin" yang menurut bahasa berarti "membentuk keluarga dengan lawan jenis, atau melakukan hubungan kelamin, bersetubuh". 3 Perkawinan disebut juga "pernikahan" yang berasal dari bahasa Arab, yakni "نكاح" yang menurut bahasa artinya "mengumpulkan, saling memasukkan, dan digunakan untuk arti bersetubuh (wathi)". 4

Menurut Mohd. Idris Ramulyo bahwa :

Nikah (kawin) menurut arti asli ialah hubungan seksual, tetapi menurut arti majazi (mathaporic) atau arti hukum ialah akad (perjanjian) yang menjadikan halal hubungan seksual sebagai suami istri antara seorang pria dengan seorang wanita. ${ }^{5}$ Sedangkan Perkawinan dari segi definisi seperti yang dirumuskan oleh Wahbah Al-Zuhaili dalam bukunya "Al-Fiqh al-Islam Wa Adillatuh" ditemukan definisi sebagai berikut :

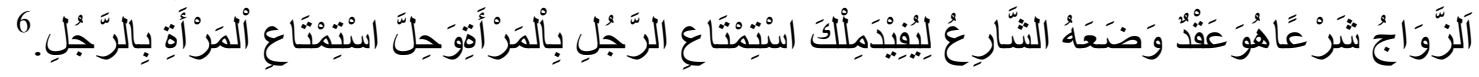

\section{Artinya:}

Perkawinan berdasarkan syari'at adalah akad yang ditetapkan syara' untuk membolehkan bersenang-senang antara laki-laki dengan perempuan dan menghalalkan bersenang-senangnya perempuan dengan laki-laki.

\footnotetext{
${ }^{3}$ Depdikbud. RI., Kamus Besar Bahasa Indonesia (Edisi III; Cet. I; Jakarta: Balai Pustaka, 2001), h. 518 .

${ }^{4}$ Abd. Rahman Ghazaly, Fiqh Munakahat (Edisi I: Cet. I; Jakarta: Prenada Media, 2003), h. 7.

${ }^{5}$ Mohd. Idris Ramulyo, Hukum Perkawinan Islam: Suatu Analisis dari Undang-undang No. 1 Tahun 1974 dan Kompilasi Hukum Islam (Edisi II; Cet. I; Jakarta: Bumi Aksara, 1996), h. 1.

${ }^{6}$ Wahbah Al-Zuhaili, Al-Fiqh Al-Islam Wa Adillatuh (Cet. III; Beirut: Dart al-Fikr, 1989), h. 29.
} 
Sedangkan berdasarkan UU Perkawinan No. 1 Tahun 1974, perkawinan didefinisikan sebagai:

Ikatan lahir batin antara seorang pria dengan seorang wanita sebagai suami istri dengan tujuan membentuk keluarga (rumah tangga) yang bahagia dan kekal berdasarkan Ketuhanan Yang Maha Esa. ${ }^{7}$

Ada pula yang mendefinisikan kata Perkawinan itu sebagai berikut :

Perkawinan (bagi manusia) adalah suatu cara yang dipilih oleh Allah sebagai jalan bagi mereka untuk mengembangkan keturunan, beranak, melestarikan kehidupannya, setelah masing-masing pasangan dari mereka (laki-laki dan perempuan) sudah siap melakukan perannya yang positif dalam mewujudkan tujuan Perkawinan. ${ }^{8}$

Dalam Kompilasi Hukum Islam pasal 2 menyebutkan bahwa perkawinan berdasarkan hukum Islam adalah "akad yang sangat kuat untuk mentaati perintah Allah dan melaksanakannya merupakan ibadah". 9 Sedangkan pasal 3 disebutkan bahwa "Perkawinan bertujuan untuk mewujudkan kehidupan rumah tangga yang sakinah, mawaddah dan rahmah". ${ }^{10}$

Berdasarkan dari beberapa defenisi tentang perkawinan yang dijelaskan diatas, maka dapat disimpulkan bahwa perkawinan merupakan suatu ikatan lahir dan batin antara laki-laki dan perempuan yang didasari dengan akad sebagai jalan yang dipilih oleh Allah sehingga menjadi sebuah ibadah kepada mereka dengan tujuan untuk membentuk kehidupan rumah tangga yang bahagia, sakinah dan mawaddah wa rahmah, berkembang biak, beranak pinak serta menyambung tali silaturrahim kepada sesama manusia.

\section{B. Mahar}

\section{Pengertian Mahar}

Mahar secara etimologi artinya maskawin, secara terminology, mahar ialah pemberian wajib calon suami kepada calon istri sebagai ketulusan hati calon suami untuk menimbulkan rasa cinta kasih bagi seseorang istri kepada calon suaminya. ${ }^{11}$

Maskawin atau mahar adalah pemberian seorang suami kepada istrinya sebelum, sesudah atau pada waktu berlangsungnya akad sebagai pemberian wajib atau sesuatu yang diserahkan oleh calon suami kepada calon istri dalam rangka akad perkawinan

\footnotetext{
${ }^{7}$ Undang-undang tentang Perkawinan, Bab I Pasal 1

${ }^{8}$ Mahtuf Ahnan dan Maria Ulfa, Risalah Fiqih Wanita: Pedoman Ibadah Kaum Wanita Muslimah dengan Berbagai Permasalahannya (Surabaya: Terbit Terang, 2000), h. 270.

${ }^{9}$ H. Abdurrahman, Kompilasi Hukum Islam di Indonesia (Jakarta: Akademika Pressindo, 1995), h. 114.

${ }^{10}$ Ibid.

${ }^{11}$ Slamet Abidin dan Aminuddin, Fiqh Munakahat (Bandung : CV. Pustaka Setia, 1999), h. 83.
} 
antara keduanya, sebagai lambang kecintaan calon suami terhadap calon istri serta kesediaan calon istri untuk menjadi istrinya. ${ }^{12}$

Mahar menurut Kompilasi Hukum Islam pada pasal 1 huruf $\mathrm{d}$ : Pemberian dari calon mempelai pria kepada calon mempelai wanita, baik berbentuk barang, uang atau jasa yang tidak bertentangan dengan hukum Islam.

Dari pengertian diatas maka dapat disimpulkan bahwa mahar dalam bahasa Indonesia sangat dikenal dengan istilah maskawin, yaitu suatu pemberian barang berharga baik berupa barang maupun jasa dari calon mempelai laki-laki kepada calon mempelai perempuan sebagai simbol kecintaan laki-laki kepada perempuan dan kesediaan perempuan untuk menjadi istri kepada laki-laki tersebut.

\section{Dasar Hukum Mahar}

Mahar merupakan suatu kewajiban yang harus dipenuhi atau diberikan calon suami kepada calon istrinya sebagai tanda kesempurnaan perkawinan yang diucapkan pada saat akad nikah. Jika serang calon suami tidak sepakat untuk menyerahkan mahar tersebut kepada calon isterinya, maka perkawinan tersebut batal atau tidak sah dalam hukum islam. Sebagaimana Firman Allah Swt dalam Q.S. an-Nișa'/4:4

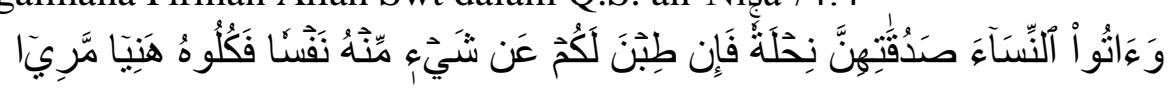

Terjemahnya :

Berikanlah maskawin (mahar) kepada wanita (yang kamu nikahi) sebagai pemberian dengan penuh kerelaan. Kemudian jika mereka menyerahkan kepada kamu sebagian dari maskawin itu dengan senang hati, maka makanlah (ambillah) pemberian itu (sebagai makanan) yang sedap lagi baik akibatnya. ${ }^{13}$

Dari ayat diatas sangat jelas bahwa maskawin (mahar) merupakan suatu kewajiban calon suami yang harus diberikan kepada calon istri dengan perasaan yang ikhlas dan rela, agar calon istri dapat menikmati pemberian tersebut.

\section{Jenis dan Syarat Mahar}

Jenis pemberian mahar dalam hukum islam tidaklah hanya terfokus pada satu jenis saja. Uama fikih sepakat bahwa mahar itu ada dua macam, yaitu mahar musamma dan mahar mitsil (sepadan). ${ }^{14}$

a. Mahar Musamma

Mahar musamma yaitu mahar yang sudah disebut atau dijanjikan kadar dan besarnya ketika akad nikah. Atau, mahar yang dinyatakan kadarnya pada waktu akad nikah. Ulama fikih telah sepakat bahwa dalam pelaksanaanya, mahar musamma harus diberikan secara penuh apabila

\footnotetext{
${ }^{12}$ Abd. Shomad, Hukum Islam Penormaan Prinsip Syariah dalam Hukum Indonesia (Jakarta : Prenada Media Group, 2010), h.299.

${ }^{13}$ Departemen Agama RI, loc. cit.

${ }^{14}$ Abd. Rahmad Ghazaly, op. cit., h. 92.
} 
telah bercampur (bersenggama) dan salah satu suami istri meninggal dunia.

b. Mahar Mitsil (sepadan)

Mahar mitsil yaitu mahar yang tidak disebut besar kadarnya pada saat sebelum ataupun ketika terjadi perkawinan. Atau mahar yang diukur (sepadan) dengan mahar yang pernah diterima oleh keluarga terdekat, agak jauh dari tetangga sekitarnya, dengan mengingat status social, kecantikan dan sebagainya.

Sedangkan syarat mahar yang diberikan calon suami kepada calon istri yang telah disepakati oleh beberapa ulama fikih yaitu: ${ }^{15}$

a. Harta/bendanya berharga. Tidak sah mahar dengan yang tidak berharga, walaupun tidak ada ketentuan banyak atau sedikitnya mahar. Akan tetapi apabila mahar sedikit tetapi bernilai maka tetap sah

b. Barangnya suci dan bisa diambil manfaat. Tidak sah mahar dengan khamar, babi, atau darah, karena semua itu haram dan tidak berharga

c. Barangnya bukan barang ghasab. Ghasab artinya mengambil barang milik orang laintan seizinnya, namun tidak bermaksud untuk memilikinya karena untuk mengembalikannya kelak. Memberikan mahar dengan barang hasil ghasab tidak sah, tetapi akadnya tetap sah

d. Bukan barang yang tidak jelas keadaannya. Tidak sah mahar dengan memberikan barang yang tidak jelas keadaannya, atau tidak disebutkan jenisnya.

\section{Uang Panaik}

\section{Pengertian Uang Panaik}

Uang Panaik merupakan sebuah istilah yang diberikan dalam tradisi pemberian sejumlah uang dari pihak calon suami ke pihak calon istri yang telah disepakati antara keluarga laki-laki dengan keluarga perempuan untuk dijadikan sebagai biaya pesta perkawinan calon istri. Uang Panaik merupakan sebuah langkah awal dalam memulai perkawinan dimana para pihak keluarga calon mempelai saling menyepakati tentang jumlah yang ditentukan oleh pihak keluarga calon istri pada saat acara lamaran.

Uang Panaik ini telah menjadi tradisi pemberian uang yang melekat kuat ditengah masyarakat dan menjadi kewajiban yang harus dipenuhi oleh setiap calon suami kemudian diserahkan kepada keluarga calon istri. Uang Panaik juga menjadi syarat yang mengikat untuk berlangsung atau tidaknya perkawinan, dimana Uang

\footnotetext{
${ }^{15}$ Abdurrahman Al Jaziry, Kitab al-Fiqh 'ala al-Madzahib al-Arba'ah, Qism Ahwal alSyakhshiyyah (Mesir: Dar al-Irsyad, th), h. 103.
} 
Panaik ini telah menjadi kewajiban calon suami dan orang tuanya untuk membiayai segala hal-hal yang berkaitan dengan pesta penikahan. ${ }^{16}$.

\section{Sejarah singkat Uang Panaik}

Tradisi Uang Panaik tentu tidak terlepas dari sejarah panjang yang pernah terjadi di daerah suku bugis-makassar. Awal mula munculnya tradisi Uang Panaik ini yaitu pada masa kerajaan Gowa Tallo pada abad ke XVII yang diketahui bahwa kerajaan Gowa mencapai puncaknya bahkan Hegemoni dan Supremasi di daerah Sulawesi Selatan, bahkan di daerah Indonesia bagian timur pada umumnya. Saat itu ketika seorang laki-laki yang ingin meminang keluarga dari kerajaan atau keturunan raja, maka dia harus membawa seserahan yang menunjukkan kemampuan mereka untuk memberikan kesejahteraan dan kenyamanan bagi istri dan anak-anaknya kelak dengan kata lain lelaki tersebut diangkat derajatnya dan isi seserahan tersebut berupa Uang Panaik yang menjadi syarat wajib dan mutlak untuk dipenuhi. Uang Panaik kemudian berkembang hingga lapisan kasta bawah bila ingin menikahi anak gadis dari masyarakat suku Bugis, anggapan mereka tentang Uang Panaik yang tinggi akan bertujuan untuk mengetahui kesungguhan laki-laki yang ingin menikahi anak gadisnya. ${ }^{17}$

Uang Panaik dalam tradisi suku bugis telah menjadi aturan main yang wajib dipenuhi calon suami dalam perkawinan. Ini merupakan salah satu tanda kesungguhan dan penghormatan kepada calon istri beserta keluarganya. Uang Panaik juga dipandang sebagai nilai soaial atau derajat sosial ditengah masyarakat, semakin tinggi Uang Panaik yang diserahkan, maka akan semakin terpandang seorang calon suami dimata masyarakat pada umumnya dan dimata calon istri pada khususnya. Hal ini dikenal dalam Bahasa bugis sebagai "siri" atau harga diri yang harus dijaga eksistensinya oleh setiap masyarakat suku bugis. Dari siri inilah yang menjadi dasar jumlah nilai dari Uang Panaik yang diserahkan seorang calon suami kepada calon istri yang akan dinikahinya.

Perkawinan dalam tradisi masyarakat suku bugis tidak bisa lepas dari pertimbangan derajat sosial dan keadaan ekonomi. Hal ini menjadi salah satu sebab lahirnya jumlah Uang Panaik yang akan diserahkan oleh calon suami kepada calon istri. Ketika seorang calon istri memiliki derajat sosial yang tinggi, maka akan sangat berpengaruh terhadap Uang Panaik beigtupun dengan keadaan ekonomi juga menjadi salah satu acuan dalam penentuan Uang Panaik perkawinan.

Melihat realitas yang terjadi saat sekarang, Uang Panaik telah lepas dari hakikatnya mengenai kesungguhan seorang laki-laki untuk menikahi wanita pilihannya. Justru Uang Panaik menjadi sebuah ajang gengsi ditengah masyakarat dan telah menjadi penyakit sosial. Mereka lebih senang dan merasa bangga serta menganggap

${ }^{16}$ Syarifuddin Latif, Fikih Perkawinan Bugis Tellumpoccoe (Tangsel: Gaung Persada Press Jakarta, 2016), h. 112.

${ }^{17}$ Andi Aminah Riski dkk, Money Shopping (Uang Panaik) In Marriage Bugis Reteh District Community Indragiri Hilir, (Jom.unri.ac.id, 2017) h. 4. 
dirinya berada pada derajat sosial yang tinggi ketika Uang Panaik yang mereka serahkan atau mereka terima juga lebih tinggi.

\section{Cara Penyerahan Uang Panaik}

Uang Panaik yang diserahkan calon suami kepada calon istri tentu memiliki tahapan dan cara tertentu sesuai dengan aturan tradisi masyarakat pada umumnya. Tahapan dan cara penyerahan Uang Panaik yaitu sebagai berikut :

a. Pihak orang tua calon suami mengutus salah seorang yang dipercayakan untuk mewakilinya sebagai pihak dari calon suami untuk menemui dan menyepakati ketentuan perkawinan kepada pihak keluarga calon istri.

b. Pihak calon suami berdiskusi dan bermusyawarah secara terbuka kepada seluruh keluarga calon istri terkait perihal tradisi perkawinan terutama jumlah nilai Uang Panaik. Perihal yang menjadi pembahasan ketika kedua pihak keluarga ini bertemu yaitu :

- Jumlah Uang Panaik

- Mahar atau maskawin

- Jumlah bosara (kue tradisi suku bugis)

- Pakaian perkawinan kedua calon mempelai

- Tanggal perkawinan

c. Setelah semua hal diatas disepakati, maka pihak keluarga calon suami kembali berunding dan bermusyawarah kemudian mempersiapkan segala hal yang telah disepakati tersebut.

d. Uang Panaik akan diserahkan sesuai dengan kesepakatan kedua belah pihak. Kadang ada yang menyerahkan sebelum akad nikah dan adapula yang menyerahkan pada saat hari akad nikah.

\section{Perbedaan Mahar dan Uang Panaik}

Mahar dan Uang Panaik tentu telah kita pahami setelah menelaah dari kedua pengertian diatas, bahwa Mahar dan Uang Panaik merupakan dua hal yang berbeda namun keduanya harus terpenuhi dalam perkawinan. Mahar tidak semahal dan setinggi nilai Uang Panaik, mahar biasanya hanya berupa tanah, cincin, emas dan uang. Akan tetapi Uang Panaik adalah sejumlah uang yang bernilai fantastis dan tidak memiliki standar jumlah yang lazim dalam tradisi masyarakat.

Mahar biasanya tidak menjadi beban kepada calon suami karena nilai dan jumlahnya sangatlah realistis. Calon suami tidak perlu menyiapkan uang dengan jumlah yang sangat banyak demi membayar atau menebus mahar tersebut. Sedangkan jumah Uang Panaik sangat bervariasi, hal ini diakibatkan dengan adanya derajat sosial dan keadaan ekonomi, mulai dari puluhan juta rupiah sampai pada ratusan juta rupiah. Tentu ini menjadi beban berat yang harus dilalui dan dipenuhi oleh calon suami. Bahkan tidak 
sedikit kasus pembatalan menikah diakibatkan Uang Panaik, karena tidak semua calon suami mampu menerima dan memenuhi permintaan Uang Panaik tersebut.

\section{METODE PENELITIAN}

Metode yang digunakan peneliti dalam penelitian ini adalah metode observasi dan interview. Observasi merupakan suatu pengamatan dan pencatatan sistematis terhadap fenomena yang diselidiki dalam hal ini penulis akan mengamati tentang perilaku atau aktivitas masyarakat. Sedangkan Interview yakni melakukan wawancara langsung kepada beberapa oknum masyarakat (tokoh masyarakat, tokoh agama, maupun pemerintah setempat) yang dianggap dapat memberikan keterangan tentang masalah yang akan dibahas. Penelitian ini ditkateogrikan dalam penelitian lapangan yang prosedur penelitiannya dapat menghasilkan data deskriptif berupa kata-kata, data tertulis atau lisan dari orang-orang yang diamati atau dijadikan sumber informasi.

\section{HASIL PENELITIAN DAN PEMBAHASAN}

\section{Eksistensi Mahar dan Uang Panaik Dalam Pelaksanaan Perkawinan dalam Tradisi Masyarakat di Kecamatan Marioriawa Kabupaten Soppeng}

\section{a. Eksistensi Mahar}

Perkawinan merupakan perintah agama sebagai manifestasi penghargaan Islam terhadap kaum wanita yang telah memberikan perhatian dan penghargaan atas kedudukan seorang wanita dengan memberi hak kepadanya, di antaranya adalah hak untuk menerima mahar. Mahar yang diberikan oleh calon suami kepada calon istri, bukan kepada wanita lainnya atau siapapun juga termasuk orang tua maupun saudara kandung. Orang lain tidak boleh menjamah atau mengambil sedikitpun dari "mahar" apalagi menggunakannya, meskipun oleh suaminya sendiri, kecuali jika dengan ridha dan kerelaan istri sendiri.

Sistem perkawinan khususnya di Kelurahan Limpomajang Kecamatan Marioriawa Kabupaten Soppeng, selain pelaksanaan perkawinan itu berdasarkan syariat Islam juga memperhatikan aspek adat istiadat. Artinya bahwa sistem perkawinan yang terjadi didalam masyarakat Limpomajang telah sejalan dengan syari'at Islam karena dilaksanakan berdasarkan syarat yang mengikuti rukunnya, yakni calon mempelai lakilaki dan perempuan, ijab dan qabul, dihadiri dua orang saksi, dan dinikahkan oleh walinya. Selain itu juga calon suami membayar dan menyerahkan mahar kepada calon istrinya. Hal ini dibuktikan dari beberapa kasus perkawinan yang pernah terjadi di Kelurahan Limpomajang, setiap calon suami wajib menyerahkan mahar kepada calon istrinya. Di Limpomajang pada khususnya memberikan istilah lain dari kata mahar yaitu sompa yang berarti penyerahan barang berharga seorang calon suami kepada calon istrinya. Biasanya sompa ini berisi sepetak sawah atau tanah, cincin emas dan juga uang tunai. 
H. Nasharuddin, BA ketika diwawancarai oleh penulis, beliau mengemukakan pendapatnya bahwa:

Sompa adalah suatu pemberian barang berharga dan bernilai yang wajib dari calon suami kepada calon istrinya. Sompa tersebut berisi salah satunya berupa sawah, kebun, cincin emas, emas 1 set, ataupun uang secara tunai, tergantung dari kesepakatan kedua belah pihak antara keluarga calon suami dan keluarga calon istri. $^{18}$

Pernyataan dari informan diatas membuktikan bahwa mahar telah eksis dan telah dilaksanakan dengan baik oleh masyarakat Limpomajang. Bahkan masyarakat telah menjadikan peryaratan yang wajib dilaksanakan oleh setiap calon suami yang akan menikah. Kajian teori diatas menyimpulkan bahwa mahar adalah pemberian wajib berupa barang berharga yang harus dipenuhi oleh calon suami kepada calon istrinya. Hal ini tidak bertentangan dengan sompa yang telah lama dikenal dan diimplementasikan oleh masyarakat Limpomajang.

Asidi ketika diwawancarai oleh penulis, juga memberikan tanggapan bahwa:

Sompa telah lama dilaksanakan oleh masyarakat Limpomajang karena merupakan sebuah pemberian wajib dari calon suami kepada calon istrinya sesuai dengan kesepakatan dari kedua belah pihak serta harus mengikuti tradisi adat suku bugis pada lazimnya. Khusus daerah Limpomajang, calon istri lebih dominan meminta 1 set perhiasan emas dengan kisaran berat 15 sampai 50 gram. ${ }^{19}$

Pernyataan dari informan diatas memberikan tanggapan bahwa sompa adalah pemberian wajib yang harus dipenuhi seorang calon suami kepada calon istrinya sesuai dengan hasil kesepakatan kedua keluarga tersebut. Bahkan sebagian masyarakat juga lebih menekankan kepada pihak keluarga calon suami terkait dengan penentuan sompa tersebut.

Penulis memandang bahwa mahar tidaklah berbeda dengan sompa yang telah lama dikenal oleh masyarakat Limpomajang. Namun mereka tetap memperhatikan dan melihat aspek adat istiadat terutama aspek hukum islam. Mahar atau sompa dijadikan sebagai acuan utama dan langkah pertama dalam perkara perkawinan, perkawinan akan dibatalkan ketika seorang calon suami tidak mampu memenuhi mahar atau sompa yang telah disepakati tersebut.

${ }^{18}$ H. Nasharuddin, BA., Imam Kelurahan Limpomajang, "wawancara”, di Kelurahan Limpomajang Kecamatan Marioriawa Kabupaten Soppeng, tanggal 7 Nopember 2019.

${ }^{19}$ Asidi., Lurah Limpomajang, “wawancara”, di Kelurahan Limpomajang Kecamatan Marioriawa Kabupaten Soppeng, tanggal 10 Nopember 2019. 


\section{b. Eksistensi Uang Panaik}

Sistem perkawinan di Kelurahan Limpomajang Kecamatan Marioriawa Kabupaten Soppeng, tatacara pelaksanaannya di samping dilakukan berdasarkan syari'at islam seperti adanya calon mempelai, dilakukan peminangan, dilaporkan kepada petugas yang berwenang dalam hal ini KUA, ada wali, ada saksi, ijab dan qabul, serta membayar mahar, dan diadakan walimah (pesta perkawinan), walaupun sekadar minum teh manis atau dengan sepotong kaki kambing untuk bahan sop. ${ }^{20}$

Pelaksanaan walimah atau pesta perkawinan yang dilakukan oleh masyarakat Kelurahan Limpomajang, walaupun dianggap sebagai suatu rukun dan syarat nikah, akan tetapi implementasinya di lapangan menurut analisis penulis kurang proporsional sebab terdapat suatu keganjalan yang perlu diluruskan. Pelaksanaan walimah, memang diakui sebagai suatu rukun dan syarat nikah berdasarkan kesepakatan ulama, khususnya ulama Indonesia, akan tetapi didalamnya tidak ditemukan siapa yang berkewajiban menanggung biaya walimah itu. Yang ada hanya berupa anjuran sebagai tanda bahwa telah resmi terjadinya akad nikah (perkawinan), sehingga biaya pelaksanaannya tidak dicantumkan.

Berkaitan dengan hal tersebut diatas, H.Nasaruddin, BA telah memaparkan kepada penulis bahwa :

Dalam pelaksanaan walimah oleh masyarakat di Kelurahan Limpomajang ini, telah menjadi suatu adat tradisi bahwa biaya pelaksanaan walimah ditanggung oleh pihak laki-laki sebesar $80 \%$, selebihnya $20 \%$ ditanggung pihak perempuan. ${ }^{21}$

Pemaparan informan diatas menunjukkan bahwa pelaksanaan walimah setelah terjadi secara resmi akad nikah oleh masyarakat Kelurahan Limpomajang menimbulkan suatu problematika tersendiri. Penanggulangan biaya walimah sangat besar dan ditanggung oleh pihak laki-laki. Oleh karena itu, biaya yang harus disiapkan oleh pihak laki-laki akan semakin membengkak, karena disamping biaya pencatatan nikah, juga biaya mahar (walaupun tidak terlalu berat), tetapi yang paling berat adalah biaya walimah atau pesta perkawinan.

Pertanggungan biaya walimah inilah yang lebih dikenal oleh masyarakat setempat dengan istilah uang panai. Menurut Agung, S.Pd.. bahwa Uang Panaik atau uang belanja dalam pelaksanaan pesta perikahan kelurahan Limpomajang ini ditanggung sebagian besar oleh pihak laki-laki". ${ }^{22}$ Pengakuan informan ini mengindikasikan bahwa biaya-biaya yang diperlukan dalam pelaksanaan perkawinan di tengah-tengah

\footnotetext{
${ }^{20}$ Mohd. Idris Ramulyo, Hukum Perkawinan Islam; Suatu Analisis dari Undang-undang No. 1 Tahun 1974 dan Kompilasi Hukum Islam (Edisi II; Cet. I; Jakarta: Bumi Aksara, 1996), h. 49.

${ }^{21}$ H. Nasharuddin, BA., Imam Kelurahan Limpomajang, "wawancara", di Kelurahan Limpomajang Kecamatan Marioriawa Kabupaten Soppeng, tanggal 7 Nopember 2019.

${ }^{22}$ Agung, S.Pd., Tokoh Pemuda Kelurahan Limpomajang, "wawancara", di Limpomajang Kecamatan Marioriawa Kabupaten Soppeng, tanggal 14 Nopember 2019.
} 
masyarakat Kelurahan Limpomajang pada umumnya ditanggung oleh pihak laki-laki, mulai dari biaya pendaftaran di P3NTR sampai pada biaya walimah.

Sukardi Mustafa, M.Ag menuturkan kepada penulis bahwa :

Masyarakat Kelurahan Limpomajang sekarang ini tampaknya telah mengalami pergeseran nilai-nilai budaya dalam perkawinan. Dimana masyarakat seakan-akan lebih mementingkan Uang Panaik atau uang belanja ini dibandingkan dengan mahar yang merupakan syarat sah dan bahkan rukun perkawinan. ${ }^{23}$

Penuturan informan diatas menggambarkan bahwa masyarakat Kelurahan Limpomajang dalam hal perkawinan seolah-olah mereka lebih mementingkan Uang Panaik ini ketimbang mahar. Mahar atau maskawin walaupun jumlahnya relatif kecil, akan tetapi merupakan persyaratan mutlak yang wajib dipenuhi oleh pihak mempelai laki-laki kepada pihak mempelai wanita. Karena memang Islam tidak menyukai mahar yang berlebih-lebihan (wanita yang memasang mahar yang terlalu tinggi). Bahkan sebaliknya, bahwa setiap mahar itu lebih murah sudah tentu akan memberi berkah dalam kehidupan berumah tangga. Mahar yang rendah adalah menunjukkan kemurahan hati calon istri, bukan berarti harga dirinya menurun atau jatuh. ${ }^{24}$

Pembayaran mahar atau maskawin memang tidak menjadi beban bagi masyarakat untuk melangsungkan perkawinan, akan tetapi yang sering menghambat pelaksanaan perkawinan khususnya bagi masyarakat Kelurahan Limpomajang adalah terkait uang belanja, karena harus ditanggung lebih banyak oleh pihak laki-laki. Pembiayaan walimah pada dasarnya tidak ditemukan adanya suatu aturan yang mengharuskan biaya walimah itu ditanggung sepenuhnya oleh pihak laki-laki. Namun, menurut H. Nurham bahwa:

Uang Panaik dikelurahan Limpomajang ini sebagai suatu tradisi lama yang harus ditanggung oleh pihak laki-laki. Oleh karena itu, keberadaannya tidak lebih dari "adat kebiasaan" bagi masyarakat, sehingga sangat sulit untuk dihindari. ${ }^{25}$

Penuturan salah satu masyarakat di atas, dapat dipahami bahwa eksistensi Uang Panaik yang sering menjadi beban bagi pihak laki-laki dalam pelaksanaan adat perkawinan di Kelurahan Limpomajang, hanya berupa "adat istiadat" dalam perkawinan. Hal ini terjadi karena tidak adanya ketentuan secara mutlak dalam hukum islam untuk menetapkan biaya walimah ditanggung oleh kedua belah pihak. Pemberlakuan pembayaran biaya walimah oleh pihak laki-laki di Kelurahan

${ }^{23}$ Sukardi Mustafa, M.Ag, Pemuka Agama Kelurahan Limpomajang,, "wawancara”, di Kelurahan Limpomajang Kecamatan Marioriawa Kabupaten Soppeng, tanggal 12 Nopember 2019.

${ }^{24}$ Mahtuf Ahnan \& Maria Ulfa, Risalah Fiqih Wanita: Pedoman Ibadah Kaum Muslimah dengan Berbagai Permasahannya (Cet. I; Surabaya: Terbit Terang, t. th.), h. 308-309.

${ }^{25}$ H. Nurham Tokoh Masyarakat Kelurahan Limpomajang, "wawancara", di Kelurahan Limpomajang Kecamatan Mariorawa Kabupaten Soppeng, tanggal 17 Nopember 2019. 
Limpomajang menurut Kamaluddin, adalah tidak lebih karena "laki-laki memiliki tanggung jawab dan kemauan untuk meminang anak perempuan orang". ${ }^{26}$

Bahkan menurut Drs. H. Muh. Asri bahwa:

Biaya walimah itu, kini sudah dianggap sebagai harga diri bagi kaum laki-laki, sehingga semakin tinggi (banyak) Uang Panaik yang ia seahkan, maka ia merasa bangga, sehingga terkadang karena pemahaman mereka sebagai harga diri, tidak jarang masyarakat (pihak laki-laki) memaksakan diri untuk membayar Uang Panaik dengan jalan meminjam, akibatnya kelak setelah selesai acara walimah, mereka terbebani dengan utang. ${ }^{27}$

Penuturan informan di atas mengindikasikan bahwa pelaksanaan walimah bagi masyarakat Kelurahan Limpomajang Kecamatan Marioriawa Kabupaten Soppeng, kini memerlukan pengkajian lebih dalam sehingga dapat memahami maksud dan tujuan Uang Panaik, serta bagaimana posisi hukumnya dalam Islam.

Berdasar dari asumsi tersebut, terindikasi bahwa masyarakat Kelurahan Limpomajang terutama dalam penyelenggaraan adat perkawinan, mereka menjadikan Uang Panaik itu sebagai salah satu syarat mutlak yang harus dibayar oleh pihak lakilaki. Oleh karena itu, biasanya sebelum dilangsungkan ijab-qabul yakni pada acara peminangan, akan menimbulkan "tarik menarik atau tarik ulur" kedua belah pihak terkait pembahasan jumlah Uang Panaik yang akan digunakan sebagai biaya walimah, padahal walimah itu dapat saja dilakukan secara sederhana bukan untuk bermegahmegah. Akibat seringnya terjadi "tarik menarik atau tawar menawar uang panai inilah yang sering membatalkan perkawinan.

Uang Panaik atau uang belanja dalam adat perkawinan masyarakat Kelurahan Limpojang pada dasarnya hanya merupakan biaya yang diperuntukkan untuk upacara walimah sebagai syarat resmi telah berlangsungnya sebuah sunnah nabi yang mulia, yakni akad nikah (perkawinan), karena memang biaya ini cukup untuk merayakan upacara syukuran atas terjadinya perkawinan. Akan tetapi, entah apa dan siapa yang memulai dan apa melatar belakangi sehingga tadinya acara walimah yang cukup sederhana tiba-tiba berubah menjadi pesta akbar, yang otomatis biayanyapun cukup besar. Perubahan atau peningkatan biaya yang signifikan inilah yang terkadang menyebabkan rencana perkawinan dibatalkan karena ketidak sanggupan calon mempelai laki-laki untuk membayar Uang Panaik.

Berangkat dari keterangan singkat di atas, maka dapat ditarik suatu kesimpulan bahwa eksistensi Uang Panaik dalam adat perkawinan masyarakat Kelurahan Limpomajang adalah hanyalah bersifat sebagai "tradisi atau adat kebiasaan masyarakat" karena biaya walimah sebagai tanda telah resmi terjadinya akad nikah (perkawinan), tidak ditentukan harus dibayar oleh pihak laki-laki. Hal ini mengindikasikan bahwa

\footnotetext{
${ }^{26}$ Kamaluddin, S.Pd., Tokoh Agama, "wawancara", di Kelurahan Limpomajang Kecamatan Marioriawa Kabupaten Soppeng, tanggal 18 November 2019.

${ }^{27}$ Drs. H. Muh. Asri, Tokoh Masyarakat, "wawancara", di Kelurahan Limpomajang Kecamatan Marioriawa Kabupaten Soppeng, tanggal 20 November 2019.
} 
biaya walimah itu dapat saja ditanggung bersama, yakni pihak-pihak laki-laki jika akan mengadakan walimah juga menanggung sendiri biaya walimah tersebut. Demikian pula sebaliknya, walimah dipihak perempuan juga dibiayai sendiri oleh pihak perempuan.

\section{Pandangan Hukum Islam terhadap Mahar dan Uang Panaik dalam Pelaksanaan Perkawinan bagi Masyarakat Kelurahan Limpomajang}

\section{a. Pandangan Hukum Islam terhadap mahar}

Islam tidak menetapkan jumlah besar atau kecilnya mahar, karena adanya perbedaan kaya miskin, sempit dan lapangnya rezki. Oleh karena itu, Islam menyerahkan masalah jumlah mahar itu berdasarkan kemampuan masing-masing orang, atau keadaan dan tradisi keluarga atau tradisi masyarakat setempat dimana akan dilangsungkan adat perkawinan.

Segala nash yang memberikan keterangan tentang mahar tidak dimaksudkan kecuali untuk menunjukkan betapa pentingnya nilai mahar atau maskawin itu, tanpa melihat besar kecilnya jumlah. Jadi mahar boleh berupa cincin emas, uang atau memberikan sesuatu yang bermanfaat misalnya mengajarkan baca tulis Alquran dan lain sebagainya, asalkan kedua belah pihak saling menyepakati ketika akan melangsungkan akad nikah.

Dalam Q.S. An-Nisa (4) : Allah menjelaskan bahwa:

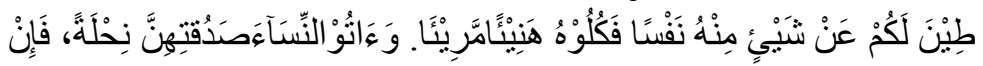

Terjemahnya:

Berikanlah maskawin (mahar) kepada wanita (yang kamu nikahi) sebagai pemberian dengan penuh kerelaan. Kemudian jika mereka menyerahkan kepada kamu sebagian dari maskawin itu dengan senang hati, maka makanlah (ambillah) pemberian itu (sebagai makanan) yang sedap lagi baik akibatnya. ${ }^{28}$

Bertolak dari firman Allah di atas, jelas tampak bahwa dalam pandangan hukum Islam, mahar adalah suatu kewajiban yang dibebankan pembayarannya kepada pihak mempelai laki-laki atas mempelai perempuan. Menurut Alham Dani bahwa mahar adalah imbangan untuk dapat menikmati tubuh si perempuan (calon istri) dan sebagai tanda kerelaan untuk diungguli oleh suaminya. Disamping itu mahar atau maskawin juga akan memperkokoh ikatan dan untuk menimbulkan kasih sayang dari istri kepada suaminya sebagai teman hidupnya. Tidak ada ketentuan yang disepakati ulama tentang batas maksimal dan minimal pemberian mahar atau maskawin. Yang jelas walaupun sedikit berdasarkan kesepakatan, ia wajib ditunaikan. Hal ini berdasarkan salah satu hadis Rasulullah saw., sebagai berikut:

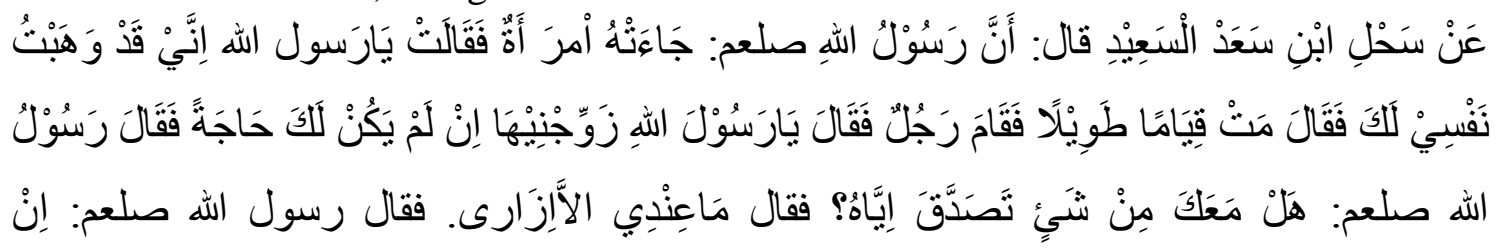

\footnotetext{
${ }^{28}$ Depag. RI., loc. cit.
} 


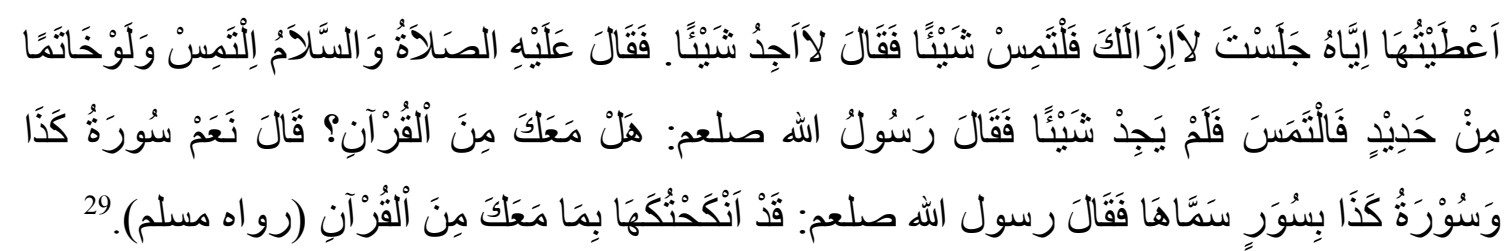

Artinya:

Dari Sahl ibn Sa'ad al-Saidi berkata bahwa Rasulullah saw., bersabda, bahwa beliau pernah didatangi seorang perempuan, kemudian mengatakan: "wahai Rasulullah saw., sungguh aku telah menyerahkan diriku kepada engkau, maka berdirilah wanita itu agak lama, tiba-tiba berdiri seorang laki-laki dan berkata: wahai Rasulullah saw., jodohkan saja dia dengan aku sekiranya engkau kurang berkenan. Rasulullah saw., bersabda: apakah kamu mempunyai sesuatu, untuk kamu berikan kepadanya (sebagai mahar)?. Laki-laki itu berkata: aku tidak mendapati sesuatu. Rasul bersabda (lagi): Carilah, walaupun sekedar cincin besi! Maka laki-laki itu mencari, dan tidak mendapati sesuatu. Lalu Rasul menanyakan lagi apakah kamu ada sesuatu dari Alquran?. Maka ia menjawab: ya, surat ini, dan surat ini, (menyebut beberapa surat). Maka Rasulullah saw., bersabda sesungguhnya aku akan menikahkan kamu dengannya, dengan (mahar) apa yang kamu miliki dari Alquran (HR. Muslim).

Jika merujuk pada hadis di atas, tampak jelas bahwa beliau tidak menyebutkan batas maksimal dan minimal jumlah mahar atau maskawin dalam perkawinan itu. Akan tetapi, tendensi hadis diatas bahwa mahar atau maskawin harus sesuatu yang berguna dan bermanfaat bagi istri, bukan pada orang lain. Hal ini menggambarkan bahwa mahar, hanyalah untuk istri semata-mata, kecuali bila istri menyerahkan sebagian maharnya itu baik kepada orang tua maupun kepada suaminya. Bahkan yang menjadi mahar berdasarkan hadis di atas hanyalah Alquran.

Dalam KHI, pasal 31 sampai pasal 32 berturut-turut disebutkan bahwa penentuan mahar berdasarkan atas kesederhanaan dan kemudahan yang dianjurkan oleh ajaran Islam, mahar diberikan langsung kepada calon mempelai wanita dan sejak itu menjadi hak pribadinya.

Penyebutan mahar dan jumlah serta bentuknya termasuk di dalamnya tunai atau tangguhnya, diucapkan pada saat akad nikah berlangsung, yaitu pada saat ijab qabul oleh wali mempelai wanita, dan dikonfirmasi dengan jawaban qabul mempelai laki-laki. Pembayaran mahar yang ditangguhkan itu tergantung pada persetujuan istri. Apabila mempelai laki-laki belum menyerahkan mahar, mempelai wanita mempunyai hak untuk menolak berhubungan suami - istri, sampai dengan dipenuhi mahar tersebut. ${ }^{30}$ Demikian juga apabila terjadi perceraian sebelum dukhul, suami wajib membayar setengah mahar yang telah ditentukan dalam akad nikah.

\footnotetext{
${ }^{29}$ Abu Husain Muslim bin Hujjaj al-Qusyairi an-Naisaburi, Shahih Muslim, Jilid 1, (Jakarta: Dar Ihya' al-Kutub al-'Arabiyah, t. th.), h. 596.

${ }^{30}$ Ahmad Rafiq, Hukum Islam di Indonesia (Cet. I: Raja Grafindo Persada: 1995)., h. 104.
} 
Hal tersebut sejalan dengan firman Allah Q.S. al-Baqarah (2) : 237 :

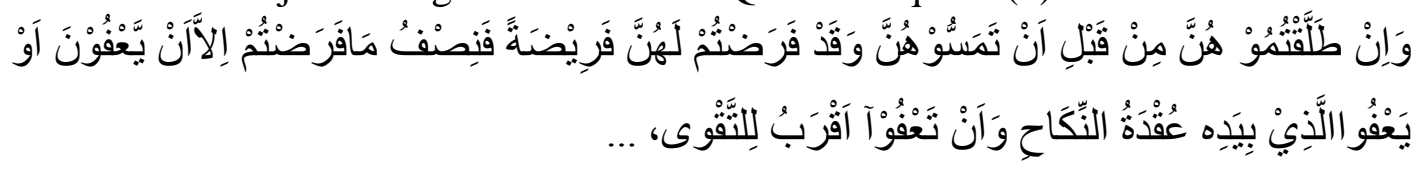

Terjemahnya:

Jika kamu menceraikan istri-istrimu sebelum kamu bercampur dengan mereka, padahal sesungguhnya kamu sudah menentukan maharnya, maka bayarlah seperdua dari mahar yang telah kamu tentukan itu, kecuali jika istri-istrimu itu mema'afkan atau dima'afkan oleh orang yang memegang ikatan nikah, dan pemaafan kamu itu lebih dekat kepada takwa, ... ${ }^{31}$.

Apabila perceraian terjadi sebelum dukhul akan tetapi besarnya mahar belum ditentukan, maka suami wajib membayar mahar mitsil yaitu mahar yang besarnya dipertimbangkan atas dasar kelayakan yang umum dimana mempelai wanita itu tinggal. ${ }^{32}$ Akan tetapi, jika suami meninggal sebelum dukhul, seluruh mahar yang telah ditetapkan menjadi hak penuh istri. (KHI pasal 35 ayat 3).

Sehubungan dengan praktek kebiasaan masyarakat seperti yang berkembang di kalangan masyarakat Limpomajang sekarang ini, yang mana calon mempelai pria memberikan sesuatu pada saat peminangan, yang disebut tunangan, seperti cincin sehingga disebut dengan cincin pengikat atau cincin tunangan. Maka pemberian serupa itu, menurut Ahmad Rofiq merupakan 'urf atau kebiasaan yang dianggap baik. ${ }^{33}$

Namun demikian apabila sehubungan dengan pemberian calon suami diluar mahar, menimbulkan permasalahan berupa selisih pendapat apakah pemberian tersebut sebagai mahar atau sebagai hadiah. Apabila dalam perselisihan itu istri menyatakannya sebagai hadiah, meski suami mengaku sebagai mahar, maka yang diterima adalah pengakuan isteri. $^{34}$

Pemberian calon suami pada saat tunangan sebaiknya dijelaskan kepada calon istri apakah sebagai mahar atau sebagai hadiah, karena kedua bentuk pemberian tersebut menimbulkan akibat hukum yang berbeda. Islam memerintahkan pemeluknya kawin dengan tujuan membina rumah tangga yang kekal, yang diridhai Allah berdasarkan kasih sayang. Namun, bila tujuan pembentukan rumah tangga tersebut gagal, maka hendaknya diselesaikan dengan cara-cara yang ma'ruf.

Bertitik tolak pada pembahasan singkat di atas, maka dapat ditarik suatu kesimpulan bahwa mahar dalam pandangan Hukum Islam adalah pemberian calon suami kepada calon istri yang wajib ditunaikan. Namun besar atau kecilnya jumlah mahar serta waktu pembayarannya tidak ditentukan oleh agama Islam, akan tetapi ditentukan oleh kesepakatan kedua belah pihak. Islam hanya mensyaratkan agar

\footnotetext{
${ }^{31}$ Departemen Agama RI., op. cit., h. 99.

${ }^{32}$ Ahmad Rafiq., op. cit., h. 105.

${ }^{33}$ Ibid., h. 106.

${ }^{34}$ Ibid.
} 
pembayaran mahar wajib ditunaikan oleh pihak calon suami, baik pembayaran tunai maupun pembayaran yang ditangguhkan.

\section{b. Pandangan Hukum Islam terhadap Uang Panaik}

Sistem tradisi atau adat perkawinan dikalangan masyarakat Kelurahan Limpomajang Kecamatan Marioriawa Kabupaten Soppeng, istilah Uang Panaik telah dikenal sejak lama bahkan telah menjadi tradisi dalam setiap perkawinan. Sedangkan uang belanja dalam Hukum Islam merupakan bagian dari nafkah yang menjadi kewajiban suami dalam rumah tangga. Artinya bahwa berlakunya kewajiban suami terhadap istri dalam hal uang belanja sebagai bagian dari nafkah, disebabkan telah terjadinya akad nikah. Asumsi ini menunjukkan bahwa Uang Panaik tidak berkolaborasi atau terpisah dengan kewajiban suami memberikan nafkah kepada istrinya (membiayai kehidupan istri dan anak-anaknya).

Sangat berbeda dengan saat sekarang ini, dimana masyarakat telah membuat adat tersendiri yang memisahkan antara mahar dan Uang Panaik. Artinya bahwa mahar atau maskawin berdiri sendiri yang peruntukkan hanya untuk istri (sebagai kewajiban suami). Sedangkan Uang Panaik yang diberikan keluarga calon suami kepada keluarga calon istri (orang tua calon istri) digunakan sebagai biaya walimah atau pelaksanaan pesta perkawinan atau resepsi perkawinan.

Ironisnya lagi karena terkadang pula ada dari pihak laki-laki yang merasa malu jika permintaan pihak perempuan ditolak, akhirnya mereka memaksakan diri untuk melangsungkan pesta perkawinan walaupun biaya walimah atau Uang Panaik terbilang mahal. Bahkan mereka tidak mereasa malu untuk meminjam uang demi melangsungkan pesta perkawinan, padahal perkawinan dapat dilangsungkan tanpa pesta yang meriah. Hanya saja, pesta perkawinan ini telah mentradisi atau telah menjadi kebiasaan dikalangan masyarakat Limpomajang, sehingga tidak ada perkawinan tanpa disertai dengan pesta, walaupun memakan biaya yang sangat besar.

Oleh karena itu, seorang istri dengan sebab adanya akad nikah menjadi terikat oleh suaminya, ia berada dibawah kekuasaan suaminya, dan suaminya berhak penuh untuk menikmati dirinya. Istri wajib taat kepada suaminya, tinggal di rumah suaminya, mengatur rumah tangga, mengasuh anak dan sebagainya. Maka Islam menetapkan suami untuk memberikan nafkah kepada istrinya selama perkawinan itu berlangsung dan si istri tidak nusyuz dan tidak ada sebab lain yang akan menyebabkan terhalangnya nafkah berdasarkan kaidah umum yang mengakui bahwa orang yang menjadi milik orang lain dan diambil manfaatnya maka nafkahnya menjadi tanggungan orang yang menguasainya.

Seperti yang pernah dikemukakan sebelumnya bahwa Uang Panaik ini tidak termasuk pada bagian mahar yang merupakan hak istri, karena Uang Panaik ini menurut tradisi atau adat masyarakat khususnya masyarakat Kelurahan Limpomajang terpisah dengan mahar. Jadi Uang Panaik ini tidak lebih dari dana atau biaya penyelenggaraan pesta perkawinan (walimah). Hal ini tidak ditemukan dalam Alquran 
maupun dalam hadis Rasulullah Saw., yang ditemukan hanyalah maskawin atau mahar. Sedangkan uang belanja (seperti disebutkan di atas) tidak ditemukan dalam Hukum Islam. Namun demikian, pemberian uang belanja dalam perkawinan itu telah menjadi adat atau tradisi dikalangan masyarakat Sulawesi Selatan terutama di kalangan masyarakat Bugis seperti masyarakat Kelurahan Limpomajang Kecamatan Marioriawa Kabupaten Soppeng.

Dalam pelaksanaan walimah ini, Mohd. Idris Ramulyo menceritakan sebuah riwayat bahwa:

Sesudah perkawinan Nabi Muhammad dengan Safiah binti Hujai bin Akhtab setelah selesai perang khaibar, Nabi berkata: beritahukanlah atau umumkanlah kepada orang sekeliling kamu perkawinan kita. Bahkan Mohd. Idris Ramulyo memaparkan bahwa berwalimahlah kamu walaupun hanya dengan menyediakan makanan yang terdiri atas kaki kambing. ${ }^{35}$

Dalam anjuran Nabi seperti yang diceritakan Mohd. Idris Ramulyo diatas, tidak ditemukan adanya penetapan biaya walimah. Akibatnya terjadi persepsi beragam dikalangan masyarakat. Ada yang menafsirkan pembiayaan walimah ditanggung sepenuhnya oleh pihak laki-laki atau sedikitnya sepertiga dari biaya yang digunakan dalam walimah itu ditanggung pihak calon mempelai laki-laki sehingga dalam pertunangan biaya walimah itu ikut dibicarakan kedua belah pihak. Adapun dampak dari adanya biaya walimah ini, terkadang biaya walimah ini menjadi pembicaraan utama atau bahkan kunci utama terjadinya perkawinan. Artinya bahwa, apabila biaya yang ditetapkan oleh pihak calon mempelai wanita tidak disanggupi pihak calon mempelai laki-laki, maka rencana perkawinan biasanya akan berakhir atau istilah masyarakat setempat adalah "pinangannya ditolak".

Dengan demikian, berlangsungnya pesta perkawinan bagi kalangan masyarakat Limpomajang sangat bergantung pada Uang Panaik yang disanggupi oleh keluarga pihak laki-laki. Sedangkan mahar (dalam istilah masyarakat Limpomajang adalah "sompa") tampaknya kurang dipikirkan oleh pihak keluarga laki-laki, sebab jumlahnya tidak sebesar Uang Panaik. Beban utama dan berat yang dipikul pihak laki-laki ketika akan melangsungkan perkawinan adalah Uang Panaik, hal ini sulit dihindari karena telah mentradisi dikalangan masyarakat Limpomajang. Walaupun pelaksanaan walimah ini dianggap sebagai sebuah sunat hukumnya,36 akan tetapi pelaksanaannya tidak dianjurkan secara besar-besaran apalagi jika perayaannya dilaksanakan dengan cara memaksakan diri. Sehingga mencari uang untuk biaya walimah tidak lagi memanandang berkah (halal atau haram) yang penting mereka mampu membiayai walimah. Jika demikian adanya, maka hukum yang tadinya "sunat" akan berubah menjadi bukan lagi sunat tetapi "haram".

\footnotetext{
${ }^{35}$ Mohd. Idris Ramulyo, op. cit., h. 54

${ }^{36}$ Ibid., h. 49.
} 
Keterangan diatas, menggambarkan bahwa biaya walimah dalam tradisi perkawinan masyarakat Kelurahan Limpomajang lebih besar ditanggung oleh pihak laki-laki, dan ditentukan oleh wali calon mempelai wanita. Oleh karena itu, jika pihak laki-laki merasa terbebani biaya walimah tersebut sementara kedua calon mempelai telah saling jatuh cinta maka mereka biasanya memutuskan sepihak. Seperti kedua calon mempelai memutuskan "kawin lari", bahkan terdapat sebagian di antara mereka yang telah mencoba menempuh jalur hukum untuk akad nikah, akan tetapi karena biaya walimah itu tidak disanggupi pihak laki-laki, akhirnya mereka berbuat nekad dengan jalan "kawin hamil" (berbuat zina), dan kedua tindakan ini tidak dikehendaki baik oleh tradisi masyarakat setempat maupun oleh agama Islam.

Fenomena masyarakat Limpomajang diatas, penulis mengkritisinya sebagai kekeliruan yang ditimbulkan oleh adanya Uang Panaik ini terletak pada wali pihak calon mempelai wanita. Sementara itu, penulis menganggap bahwa barangsiapa yang mempersulit perkawinan tanpa alasan yang dibenarkan oleh agama, niscaya sama halnya dengan mendorong seseorang untuk melakukan perbuatan maksiat. Hal ini disebabkan tujuan perkawinan itu antara lain adalah menghindarkan seseorang dari godaan setan, baik melalui penglihatan mata maupun alat kelamin atau syahwat, nafsu dan sebagainya.

Berangkat dari keterangan singkat diatas, maka dapat disimpulkan bahwa Uang Panaik yang dibayarkan oleh pihak calon mempelai laki-laki kepada pihak calon mempelai wanita sebagai biaya walimah eksistensinya tidak lain hanyalah berupa adat istiadat atau tradisi masyarakat setempat saja, sebab dalam pembiayaan walimah dana yang digunakan tidak ditentukan harus dibiayai oleh pihak siapa.

Oleh karena itu, ada baiknya tradisi masyarakat Limpomajang yang menetapkan biaya walimah pada pihak calon mempelai laki-laki dilakukan pengkajian ulang sehingga tidak memberatkan pihak laki-laki dalam melangsungkan perkawinan. Sebab jangan sampai terjadi pembatalan perkawinan hanya karena tingginya beban Uang Panaik yang harus dibayar pihak laki-laki. Semestinya, biaya walimah ditanggung masing-masing pihak dan jikalau ada bantuan dari pihak laki-laki cukup berdasarkan kemampuan dan keikhlasan pihak laki-laki sendiri, tidak ditentukan oleh pihak mempelai wanita.

\section{SIMPULAN}

Berdasarkan rumusan masalah sebelumnya, hasil penelitian dan temuan peneliti yang sudah dilakukan, maka diambil kesimpulan sebagai berikut :

1. Eksistensi mahar di Kelurahan Limpomajang Kecamatan Marioriawa Kabupaten Soppeng dalam pandangan masyakarat merupakan salah satu syarat wajib yang harus dipenuhi oleh calon suami untuk diserahkan kepada calon istri, biasanya berupa cincin emas, tanah, sawah, kebun ataupun seperangkat alat shalat. Sedangkan Uang Panaik hanyalah berupa tradisi yang telah ditetapkan secara turun temurun, dimana seorang calon suami harus memenuhi dan menyerahkan 
sejumlah uang yang sangat besar sebagaimana kesepakatan dari kedua belah pihak untuk menjadi biaya walimah kepada calon istri.

2. Pandangan Hukum Islam terkait mahar yaitu salah satu syarat wajib dalam perkawinan yang telah ditetapkan dalam Hukum Islam untuk dipenuhi oleh seorang calon suami baik itu berupa barang maupun jasa, selama barang dan jasa tersebut mengandung manfaat dan nilai. Sedangkan Uang Panaik tidak memiliki dasar dalam Alquran maupun Hadis serta Ijma, namun yang menjadi dasar adanya Uang Panaik ini hanyalah tradisi atau adat kebiasaan masyarakat setempat. Uang Panaik mengandung hukum mubah selama masih menjadi dasar tolong menolong dalam mewujudkan pernikahan. Namun akan menjadi haram ketika cara mendapatkan Uang Panaik tersebut bertentangan dengan Syariat Islam serta akan menjadi makruh ketika seorang calon suami merasa sangat berat dalam memenuhi Uang Panaik yang telah ditentukan.

\section{DAFTAR PUSTAKA}

Ahmad A, Sewang, Islamisasi Kerajaan Gowa : Abad XVI sampai Abad XVII, Jakarta: Yayasan Obor Indonesia, 2005.

Abdurrahman, H., Kompilasi Hukum Islam di Indonesia. Jakarta: Akademika Pressindo, 1995.

Abidin, Slamet dan Aminuddin, Fiqih Munakahat 1 untuk Fakultas Syari'at Komponen $M K D K$. Cet. I; Bandung: Pustaka Setia, 1999.

Ahnan, Mahtuf dan Ny. Mariah Ulfah, Risalah Fiqih Wanita (Pedoman Ibadah Kaum Wanita Muslimah dengan Berbagai Permasalahannya). Surabaya: Terbit Terang, 2001.

Alhamdani, H.S.A., Risalah Nikah (Hukum Perkawinan Islam). Cet. I; Jakarta: Pustaka Amani, 1989.

Al-Jamal, Ibrahim Muhammad, Fiqh al-Mar'ah al-Muslimat diterjemahkan oleh Anshori Umar Sitanggul, dengan judul "Fiqih Wanita”. Cet. I; Semarang: AsySyifa, t.th..

Al-San'any, Subul Al-Salam, Juz 3, Kairo: Dar Ihya' al-Turas al-Araby, 1379 H/1980 M.

Al-Zuhaili, Wahbah, Al-Fiqh Al-Islam Wa Adillatuh. Cet. III; Beirut: Dart al-Fikr, 1989. 
Departemen Agama RI., Al-Qur'an dan Terjemahnya. Semarang: Toha Putra,1989.

Depdiknas RI., Kamus Besar Bahasa Indonesia. Edisi III; Cet. I; Jakarta: Balai Pustaka, 2001.

Ghazaly, Abd. Rahman, Fiqh Munakahat. Edisi I: Cet. I; Jakarta: Prenada Media, 2003.

Latif, Syarifuddin, Fikih Perkawinan Bugis Tellumpoccoe, Tangsel: Gaung Persada Press Jakarta, 2016.

Mubarak, Jaih, Modifikasi Hukum Islam (Studi Tentang Qawl Qadim dan Qawl Jadid). Edisi 1; Cet. 1; Jakarta: RajaGrafindo Persada, 2002.

Nur, Djamaan, Fiqih Munakahat. Cet. I; Semarang: Toha Putra, 1991.

Ramulyo, Mohd. Idris, Hukum Perkawinan Islam: Suatu Analisis dari Undang-undang No. 1 Tahun 1974 dan Kompilasi Hukum Islam. Edisi II; Cet. I; Jakarta: Bumi Aksara, 1996.

Riski, Andi Aminah, Money Shopping (Uang Panaik) In Marriage Bugis Reteh District Community Indragiri Hilir, Jom.unri.ac.id, 2017.

Sabiq, Sayyid, Fiqh al-Sunnah Jilid 7yang diterjemahkan oleh Moh. Thalib dengan judul “Fikih Sunnah Jilid 77’. Bandung: Al-Ma'arif, 1990.

Sabiq, Sayyid, Fiqh Sunnah, (Jilid 6 Edisi Indonesia) diterjemahkan oleh Moh. Thalib.

Cet. VII; Bandung: Alma'arif, 1990. 